\title{
Funkční poruchy hybnosti - slovo úvodem
}

\author{
prof. MUDr. Jan Roth, CSc., MUDr. Tereza Serranová, Ph.D. \\ Neurologická klinika a Centrum klinických neurověd, Univerzita Karlova v Praze, \\ 1. LF a VFN v Praze
}

Funkční poruchy hybnosti (FPH) zahrnují různorodé spektrum neurologických problémů, které nejsou vysvětlitelné strukturálním postižením nebo neurochemickou poruchou. Obtíže nejsou produkované vědomě - nejedná se tedy ani o faktitivní poruchu ani o simulaci.

Vyskytují se mnohem častěji, než je všeobecná lékařská představa. Podle Stonea (Stone, 2009) až $50 \%$ všech ambulantních neurologických pacientů má nějaký funkční problém, který však nedominuje v klinickém obrazu. U cca $30 \%$ všech ambulantních pacientů je patrný zřetelný překryv organických a funkčních obtíží a přibližně $15 \%$ všech ambulantních pacientů má primární FPH. S FPH se tedy setkáváme $\checkmark$ běžných neurologických ambulancích a odděleních často.

\section{LITERATURA}

1. Hallett M. Physiology of psychogenic movement disorders. J Clin Neurosci. 2010; 17(8): 959-965.

2. Ellenstein A, Kranick SM, Hallett M. An update on psychogenic movement disorders. Curr Neurol Neurosci Rep. 2011; 11(4): 396-403. $\checkmark$ extrapyramidových centrech vídáme až $10 \%$ všech konzultovaných nemocných s FPH. Nejčastějšími typy jsou dystonie, tremor, myoklonus a poruchy chůze. Dřive pozorované funkční parézy či plegie jsou relativně vzácnější.

FPH jsou velkou výzvou a bohužel až doposud budí velké rozpaky pro ošetřující lékaře, a to jak z hlediska diagnostiky, tak léčby.

Etiopatogeneze pohližející na FPH z hlediska biologických mechanizmů je zatím zcela nejasná, výzkum teprve začíná. Je však již známo, že na funkčních zobrazovacích a elektrofyziologických metodách existují detekovatelné a specifické změny (Hallett, 2010; Ellenstein et al., 2011; Edwards et al., 2013).

3. Stone J. The bare essentials: Functional symptoms in neurology. Pract Neurol. 2009; 9(3): 179-189.

4. Edwards MJ, Fotopoulou A, Pareés I. Neurobiology of functional (psychogenic) movement disorders. Curr Opin Neurol. 2013; 26(4): 442-447.

\section{Základní principy}

\section{diagnostického uvažování}

- Diagnostika FPH je založena na podkladě splnění diagnostických kritérií, nikoliv principem per exclusionem, tj. vyloučením všech možných příčin „organicity”.

- Bizarní pohybový projev neznamená sám o sobě FPH! Známe mnoho prípadů na první pohled zcela bizarních poruch hybnosti, které byly způsobeny organickou poruchou (některé dystonické syndromy, pozdní hybné komplikace Parkinsonovy nemoci, tardivní dyskineze atd.).

- Neexistuje žádná pomocná vyšetřovací metoda jednoznačně potvrzující či vylučující funkční původ hybné poruchy (s výjimkou myoklonu a velmi vzácného parkinsonského syndromu funkčního původu). 